\title{
Should nylon corneal sutures be routinely removed?
}

\author{
Heather Jackson, Robin Bosanquet
}

\begin{abstract}
Three groups of patients who had undergone cataract extraction through a corneal incision closed with 10/0 nylon sutures one, two, and three years previously were recalled to determine the incidence of suture related complications. Broken corneal sutures were found in $87.5 \%$ of patients after two years and $90 \%$ after three years and were causing symptoms in over half the patients. It is recommended that $10 / 0$ nylon corneal sutures be routinely removed no later than one year after surgery.
\end{abstract}

Opinion is divided on whether $10 / 0$ nylon corneal sutures need to be removed following cataract surgery. Often removal of the sutures will be required to correct postoperative astigmatism. However, in those cases without significant astigmatism the authors adopted the policy of leaving the sutures in situ on the grounds of saving time in the clinic, avoiding a second refraction for the patient, and avoiding the small risk of a wound leak at the time of removal. The argument for removing all corneal sutures as a routine is that the nylon gradually degrades and some patients may suffer discomfort from the protruding ends of broken sutures.

In this study we aimed to assess the incidence of complications by reviewing patients who had undergone cataract surgery one, two, and three years previously and whose corneal sutures had been left in place.

\section{Material and methods}

The records of patients who had undergone cataract extraction with intraocular lens implantation and whose corneal sections had been closed with 10/0 nylon during the months of April to September 1987, April to June 1988, and April to June 1989 were reviewed. In 1987 many patients still had corneoscleral incisions closed with virgin silk, and so it proved necessary to take a longer period in order to include sufficient patients with $10 / 0$ nylon sutures. Those patients who had corneal sutures removed because of astigmatism (Table 1) were excluded. There were thus three groups of patients with corneal sutures in situ who had undergone surgery approximately one, two, and three years ago.

Ophthalmology,

Newcastle General

Hospital, Newcastle

upon Tyne

R Bosanquet

Correspondence to:

R Bosanquet, FCOphth, Department of

Ophthalmology, Newcastle General Hospital, Newcastle upon Tyne NE4 6BE

Accepted for publication 11 April 1991

$\star$ Present address: Department of Ophthalmology, St George's London SW17 0QT

\begin{tabular}{llll}
\hline & $\begin{array}{l}1989 \\
(1 \text { year })\end{array}$ & $\begin{array}{l}1988 \\
(2 \text { years })\end{array}$ & $\begin{array}{l}1987 \\
(3 \text { years })\end{array}$ \\
\hline $\begin{array}{l}\text { No of patients with nylon sutures } \\
\text { No of patients who had sutures removed: }\end{array}$ & 39 & 26 & 32 \\
$\quad$ (i) for astigmatism & 6 & 0 & 6 \\
$\quad$ (ii) for other reasons & 3 & 2 & 2 \\
Died & 2 & 4 & 2 \\
Unable to attend for review & 1 & 4 & 2 \\
Patients reviewed for study & 27 & 16 & 20 \\
\hline
\end{tabular}

Patients were recalled by the authors and were asked about symptoms which could be related to their corneal sutures. During the examination we looked for signs of giant papillary conjunctivitis and noted the condition of the corneal sutures. We classified our findings into three groups: (i) patients with intact sutures and without symptoms; (ii) patients with broken sutures but without symptoms; (iii) patients with broken sutures and related symptoms.

\section{Results}

Table 1 shows the composition of the three groups of patients and Table 2 summarises the findings on examination of these groups. They show that, while over $80 \%$ of patients will have intact corneal sutures at one year, this figure will have fallen to $10 \%$ by the third year postoperatively. After three years $50 \%$ of our patients had symptoms related to their broken sutures. These ranged from a minor foreign body sensation in the eye to discomfort which was sufficiently severe in two cases for the patient to be referred to the eye casualty department.

Suturing techniques changed during the three years covered by this study. In 1987 all patients had interrupted sutures; in 1988 they all had continuous sutures; while in 1989 half were continuous and half interrupted. It is worth noting that three of the four patients with broken sutures and the one patient with symptoms were in the continuous suture group.

\section{Discussion}

The complications associated with nylon corneal sutures have been well documented ${ }^{1-3}$ and are caused by protruding broken ends of the suture. McClellan $e t ~ a l^{4}$ found evidence on scanning electron microscopy of surface disintegration on $10 / 0$ nylon sutures after three months. Rijneveld et $a l^{5}$ described the tissue reaction to nylon sutures.

In this series there were very few problems associated with nylon corneal sutures during the first year, but thereafter the incidence of symptoms increased. The patients' main complaint was of a recurrent gritty sensation. On examination the broken protruding suture ends were usually associated with marked vascularisation

\section{Table 2 Findings on examination}

\begin{tabular}{|c|c|c|c|}
\hline & 1 year & 2 years & 3 years \\
\hline Intact sutures & $22(81 \cdot 5 \%)$ & $2(12 \cdot 5 \%)$ & $2\left(10^{\circ} 0\right)$ \\
\hline $\begin{array}{l}\text { Broken sutures without } \\
\text { symptoms }\end{array}$ & $4(1+\cdot 8 \%)$ & $5(31 \cdot 2 \%)$ & $.8(40 \%)$ \\
\hline Broken sutures with symptoms & $1(3 \cdot 7 \%)$ & $9(56 \cdot 2 \%)$ & $10\left(50^{\circ}{ }_{0}\right)$ \\
\hline $\begin{array}{l}\text { Giant papillary conjunctivitis } \\
\text { with broken sutures }\end{array}$ & 0 & $1(6 \cdot 2 \%)$ & $1\left(4^{0} 0\right)$ \\
\hline
\end{tabular}


Figure 1 Vascularisation associated with broken interrupted $10 / 0$ nylon corneal sutures.

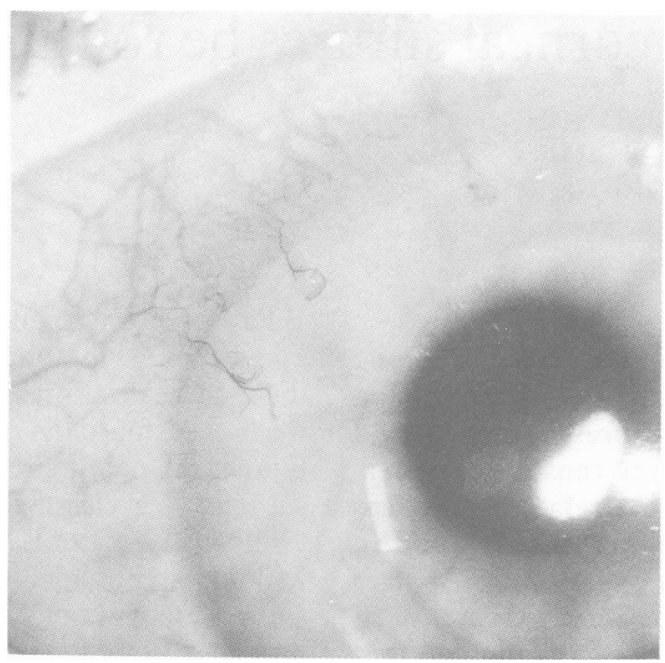

(Fig 1) and often accumulation of mucus. Two patients with broken sutures had giant papillary conjunctivitis. In all cases the removal of the offending sutures resulted in rapid relief of symptoms and resolution of the signs.
These results reinforce the conclusions of Acheson and Lyons ${ }^{6}$ that 10/0 nylon corneal sutures should be removed within 12 months of surgery. The longer that sutures are left in situ the greater the chance that they will cause symptoms. Moreover, once disintegration of the suture has begun, removal becomes progressively more difficult because the suture tends to break when it is pulled through the tissues.

We recommend that $10 / 0$ nylon corneal sutures should be removed between three months and a year after cataract surgery.

1 Nirankari VS, Karesh JW, Richards RD. Complications of exposed monofilament sutures. Am F Ophthalmol 1983; 95: 515-9.

2 Friedman T, Friedman Z, Neumann E. Giant papillary conjunctivitis following cataract extraction. Ann Ophthalmol 1984; 16: 50-2.

3 Wille H, Mølgaard IL. Giant papillary conjunctivitis in connection with corneoscleral Supramid (nylon) suture knots. Acta Ophthalmol $(K G h)$ 1984; 62 (1): 75-83

4 McLellan KA, Knol A, Billson FA. Nonabsorbable suture material in corneoscleral sections - a comparison of Novafil and nylon. Ophthalmic Surg 1989; 20: 480-5.

5 Rijneveld WJ, Jongebloed WL, Worst JGF, Houtman WA. Comparison of the reaction of the cornea to nylon and stainless steel sutures: an animal study. Doc Ophthalmol 1989; 72: 297-307.

6 Acheson JF, Lyons CJ. Ocular morbidity due to monofilament nylon corneal sutures. Eye 1991; 5: 106-12.

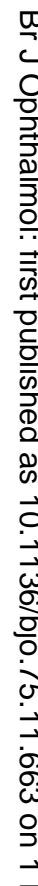

